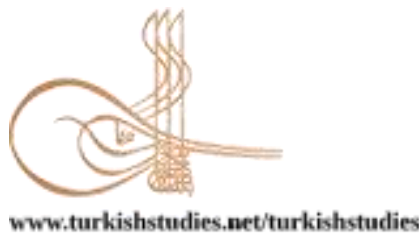

Turkish Studies

\title{
Uluslararası Diplomasi Aracı Olarak Terörizm ve Türkiye
}

\author{
Terrorism as a Tool of International Diplomacy and Turkey
}

\author{
Türkmen Töreli*
}

\begin{abstract}
In the period before the Industrial Revolution, diplomacy tools were the use of military force, granting economic resources as a concession, or applying them as an embargo, hostage procedure, and political marriages. After the Industrial Revolution, some diplomacy tools lost their importance, and some changed. New ones have been added to them. Technology and capital transfer, missionary schools, incitement, and promotion of nationalism are new tools of diplomacy. Our subject matter, the use of terrorism as a tool of diplomacy, is also the most destructive tool of the modern era. The nationalistic feelings of different ethnic and religious elements in the countries targeted by the imperialists were provoked, then they were revolted for a simple reason. As a result of this, the Balkan territories of the Ottoman Empire were shared. There were two great world wars in the 20th century, and these wars caused great destruction. For imperialist states to dominate target countries with their armies and human forces, was expensive and carried political risks. For that reason, as in the 19th century, they provoked different ethnic elements to revolt. They have established terrorist organizations such as the PKK, PYD, and ISIL against Turkey. The vast majority of European states, especially the United States, support terrorist organizations and provide all kinds of facilities to host them in their countries. For forty years, thousands of women, children, young, elderly, and security forces have been slaughtered, and hundreds of villages have been evacuated in the terrorist attacks against Turkey. The purpose of all terrorist activities is obvious, and that is the division of Turkey. Of course, Turkey has measures to take against it, and these measures continue with determination.
\end{abstract}

Structured Abstract: Technology and capital transfer, missionary schools, incitement, and promotion of nationalism are new tools of diplomacy. Our subject matter, the use of terrorism as a tool of diplomacy, is also the most destructive tool of the modern era. Imperialist states have established terrorist organizations such as the PKK, PYD, and ISIL against Turkey. The vast majority of European nations, especially the United States, support terrorist organizations and provide all kinds of facilities to host them in their countries. For forty years, thousands of women, children, young, elderly, and security forces have been slaughtered, and hundreds of villages have been evacuated in the terrorist attacks against Turkey. The purpose of all terrorist activities is obvious, and that is the division of Turkey. Turkey has measures to take against it, and these measures continue with determination. For more than 40 years, an unnamed war has been waged against Turkey. According to the calculations, $\$ 700$ billion has been spent so far in the fight against terrorism. At least the same amount of

\footnotetext{
${ }^{*}$ Doç. Dr., Dokuz Eylül Üniversitesi, Edebiyat Fakültesi, Tarih Bölümü

Assoc. Prof., Dokuz Eylul University, Faculty of Letters, Department of History

ORCID 0000-0002-7486-523X

turkmen.toreli@deu.edu.tr

Cite as/ Atıf: Töreli T. (2020). Uluslararası diplomasi aracı olarak terörizm ve Türkiye. Turkish Studies, 15(3), 2061-

2072. https://dx.doi.org/10.29228/TurkishStudies.43317

Received/Geliş: 02 May/Mayıs 2020

Accepted/Kabul: 20 June/Haziran 2020

Checked by plagiarism software

Copyright $\odot$ MDE, Turkey

Published/Yayın: 25 June/Haziran 2020

CC BY-NC 4.0
} 
economic loss is created by the terror environment. That makes about $\$ 1.5$ trillion. The loss of this wealth from our national product has caused considerable damage to our country's economy.

This study tries to deal with its subject matter in three parts - the first part, which is about the development and changes after the industrial revolution, focuses on international diplomacy tools of the time. The second part deals with terrorism as a new diplomacy tool and analyzes past and present situations. Finally, the third chapter entitled Terrorism and Turkey concentrate on the current issues.

After the Industrial Revolution, the vast extent of colonialism has led to international competition, and finally, this competition resulted in the First World War. During the 20th century, allegations of endless competition and sharing led to a second war. Imperialist countries have discovered new tools of diplomacy for the realization of their national interests. Terrorism was among the first of these new tools, and they used it in the Balkan rebellions since the $19^{\text {th }}$ century. The Rumelia lands of the Ottoman Empire were shared with terrorism. Although it is said that "terrorism cannot get anywhere," history is the witness of its opposite. The target of imperialism, terrorism against Turkey, has been used as a means of diplomacy for many years. Terrorism is supported by the imperialists with all kinds of weapons, tools, in administrative and diplomatic areas. All of these events happen apparently and are known. So we can summarize what should be done as a countermeasure and what our proposals should be as follows:

First of all, mental change is needed. To date, there has always been a passive attitude toward the West. The policies of the United States and Europe have been important in every step taken. Every Year on April 24th, there has been great curiosity and concern about what term the US president will pronounce about the Armenian Issue. Policies based on confidence in our strength should be developed.

Technology is no longer a secret. Turkey is also capable of having all kinds of technology. In this regard, the superiority of the West has lost its importance. Nuclear energy even exists in India, Israel, and Iran. Turkey is also strong enough to produce this technology.

Reciprocity is a principal in international politics. Therefore, political and economic countermeasures should be applied against countries that are hostile to us and are arming terrorists for whatever reason. Although we know that it is difficult to put into effect since we are a part of specific agreements, US bases can be closed or limited. Also, we should withdraw our application to the EU as soon as possible, which no longer matters.

The most powerful of the means of diplomacy is the use of military force, which never loses its importance. Imperialist states established colonial orders and world domination with their military forces. In this case, Turkey should be stable militarily and economically. The Turkish military operations in Iraq and Syria have disrupted the known plans. It is now a fact that Turkey is the master of geography. Positive results are obtained when geographical superiority is combined with military power.

Furthermore, diplomatic tools should not be neglected. The massacres carried out by the imperialists in history should be condemned by the decisions taken in parliament and moved to the world public and international courts. They should never be allowed to take advantage of the country's resources in any way. Governments may not make formal statements on all issues. In this case, activities can be carried out by our national policies through non-governmental organizations. For example, our non-governmental organizations can declare August 6th and 9th as "Sharing the Pain of Japan Day" and participate in ceremonies held on these dates. Mainly if it is spread on social media, the attitude of the United States will be a matter of curiosity. We must not forget that the West relies on us more than we rely on the West.

Keywords: History, Terrorism, Turkey, International Diplomacy, Terrorist Organizations.

Öz: Sanayi İnkılabı öncesi dönemde diplomasi araçları askeri güç kullanımı, iktisadi kaynakların imtiyaz olarak verilmesi veya ambargo şeklinde uygulanması, rehin usulü ve siyasi evliliklerdi. Sanayi İnkılabından sonra bazı diplomasi araçları önemini yitirdi, bazısı da değişikliğe uğradı. Bunlara yenileri eklendi. Teknoloji ve sermaye transferi, misyoner okulları, milliyetçiliğin tahrik ve teşvik edilmesi, yeni diplomasi araçlarıdır. Konumuz olan terörizmin diplomasi aracı olarak kullanılması da yeni dönemin en yıkıcı aracıdır. Emperyalistlerin hedefi olan ülkelerdeki farklı etnik ve dini unsurların milliyetçilik duyguları tahrik edildi, sonra basit bir sebeple isyan ettirildiler. Bunun sonucu olarak Osmanlı Devletinin Balkan toprakları paylaşıldı. 20. yüzyılda iki büyük dünya savaşı yaşandı ve bu savaşlar çok büyük yıkımlara sebep oldu. Emperyalist 
devletler için artık kendi orduları ve insan güçleriyle hedef ülkelerde hâkimiyet kurmak pahalı ve siyasi riskler taşıyordu. Onun için tıpkı 19. yüzyılda olduğu gibi farklı etnik unsurları tahrik ederek ayaklandırdılar. Özellikle Türkiye'ye karşı PKK, PYD ve IŞİD gibi terör örgütlerini kurdular. Başta ABD olmak üzere Avrupa devletlerinin büyük çoğunluğu, terör örgütlerini desteklemekte, ülkelerinde barındırmakta ve onlara her türlü kolaylığı sağlamaktadır. Kırk yıldan beri Türkiye'ye karşı yürütülen terör saldırılarında kadın, çocuk, genç, ihtiyar ve güvenlik kuvvetlerimizden binlerce insanı katlettiler, yüzlerce köy boşaltıldı. Bütün terörist faaliyetlerin amacı çok açıktır, o da Türkiye'nin bölünmesidir. Elbette Türkiye'nin buna karşı alacağı tedbirleri vardır ve bu tedbirler kararlılıkla devam etmektedir.

Anahtar Kelimeler: Tarih, Terörizm, Türkiye, Uluslararası Diplomasi, Terör Örgütleri.

\section{Giriş}

Tarihte ve günümüzde her devletin menfaati olan komşu veya rakibi devletlere karşı siyasi, askeri ve iktisadi hedefleri vardır. Bu hedeflerin tahakkuku için kullanılan araçlara da siyasi/diplomasi araçları denir. Elbette bu araçlar zamanın siyasi, sosyal ve iktisadi şartlarına göre belirlenirdi. Klâsik dönem dediğimiz sanayi öncesi devletlerin genel karakteristik özellikleri şunlard1:

Çağlar boyunca bütün devlette tek kişinin hâkimiyeti vardı. Tek kişinin hâkimiyeti saltanat ailesini oluşturmuştur. Saltanat ile devlet özdeşleşmiştir. Bütün mülk devletin yani saltanatındı. Saltanatın bütün erkek ve kız üyeleri saltanatın meşru ve hukuki varisleriydi. Siyasi iktidarın meşruiyet kaynağ 1 kutsallık yani din idi. Zirai ekonomi hâkim olup, para ekonomisi yeterince gelişmemiştir. Enerji kaynakları, insan ve hayvanın kas gücü ile su ve havanın kaldırma ve itme gücü olan tabii enerji kaynaklarıydı. Üretim, haberleşme, ulaşım ve nakliye de bu enerji kaynaklarına bağlıydı. Bu dönem, imparatorluklar çağı olduğundan imparatorlukların halkı da çeşitli etnik ve dini unsurlardan oluşurdu. Kölelik, dönemin bariz bir müessesesidir.

Bu özellikleri ile klâsik dönem devletlerinin diplomasi araçları da aynı idi. Bunlar; askeri güç kullanımı, iktisadi güç unsurlarının imtiyaz verme veya ambargo şeklinde uygulanması, rehin usulü ve siyasi evliliklerdi. Uzun yıllar uluslararası ilişkilerde bu usuller kullanıldı (Öztürk, 2014: 228, 266-272).

18. yüzyılın sonlarında doğup gelişen Sanayi İnkılabı dünyada yeni bir dönemin başlamasına sebep oldu. Buhar enerjisinin bulunmas1, pratik hayata uyarlanması ile birim zamandan birim alandan alınan mal ve hizmet arttı, üretim eskiye oranla inanılmayacak derecede yükseldi, uzun mesafeler kısaldı, taşıma kapasitesi arttı. Böylece 19. yüzyılda iktisadi faaliyetlerin ve ticaretin hacmi arttı ve tabii var olan sömürgecilik daha da genişledi, sanayileşen devletler arasında yeni kaynakların elde edilmesi için büyük bir rekabet başladı.

Çünkü sömürgeciliğin üç ana hedefi vardır: Bunlar, hammadde kaynaklarına ulaşmak ve hâkim olmak, mamul hale getirilen ham maddenin nakde çevrilmesi için pazar bulma ve ham madde kaynakları ile pazarlara giden ana yolları kontrol etmekti. Sömürgeciliğin amaçları ve araçları günümüzde de değişmemiştir.

\section{Sanayi İnkılabı Sonrasındaki Gelişme ve Değişmeler}

Sanayi İnkılabı ile aynı çağda meydana gelen ve fikirleri ile dünyaya yeni usuller, anlayışlar getiren Fransız İhtilali, Sanayi İnkılabının adeta kültürel yanını tamamlar niteliktedir. Sanayi İnkılabı ile birlikte sömürgeciliğin hız kazanması neticesinde, sanayileşmiş ülkeler tarafından dünyanın çeşitli bölgelerine büyük miktarda sermaye ve teknoloji ihracı yapılmıştı. Ancak ihraç edilen sermaye ve yapılan yatırımların sağlam garantileri yoktu. Karşı devlet her zaman umulmadık kararlar alabilir, yatırımlara el koyabilir, devletleştirebilirdi. $O$ halde Batılı gelişmiş sermayedar ülkeler, bizzat kontrolü ellerine almalı ve yatırımlarını garanti altına almalıydılar. İşte burada Fransız İhtilalinin 
dünya siyasi literatürüne kazandırdığı yeni bir diplomasi aracı olan milliyetçilik fikrinden faydalanıldı. Ve milliyetçilik fikri, yeni dönemin en kuvvetli diplomasi aracı haline geldi.

Fransız İhtilali ilk defa milliyetçilik fikrini doğurmamıştır. Fransız İhtilali, askeri, siyasi ve iktisadi menfaatlerini tahkim etmek için, nüfuz alanı olarak gördükleri devletlerin farklı etnik ve dini unsurlarını tahrik, teşvik ve kullanma metotlarını dünya siyasi literatürüne getirdi. Bu yeni diplomasi aracı 19. yüzyılda o kadar çok kullanıldı ki, (şimdiye kadar yanlış olarak) 19. yüzyıla hep milliyetçilik yüzyılı dendi. $\mathrm{Bu}$ yüzyıl, milliyetçiliğin tabii bir seyir halinde geliştiği yüzyıl değil, aksine milliyetçilik fikrinin, yeni dönemde yeni bir diplomasi aracı olarak yaygın bir şekilde kullanıldığ 1 yüzyıldır. Bu yüzden 19. yüzyılda milli karakterli isyanlar baş gösterdi.

İsyan görülen her yerde, her olayda Batılı bir veya birkaç devletin taraf, isyan bittikten sonra da oralarda mandater olarak bulunmaları ilginçtir. Ancak her nasılsa bu uyum, özellikle de bizim tarihçilerimizin dikkatlerinden kaçmıştır. Sanayi İnkılabı, daha çok batı Avrupa'da geliştiği için, tabii olarak sanayi sonrası bütün diplomasi araçları, bu bölgenin devletleri tarafından kullanılacak ve söz konusu devletler sömürgecilikte başı çekeceklerdir. Onun için sömürgecilik ve sonrası bütün gelişmelerde bu devletler karşımıza çıkmaktadır. Bunlar, İngiltere, Fransa, Almanya, Belçika, Hollanda, İspanya ve Portekiz'dir. Dünyanın herhangi bir bölgesindeki milletlerarası bir meselede mutlaka bu devletlerden bir veya birkaçı vardır. ABD ise daha geç denecek bir dönemde sömürgecilik hareketlerine katılmıştır.

Sanayi İnkılabından sonra mutlak monarşiler giderek meşruti monarşiye dönüştü, anayasal dönem başladı. Diplomasi araçlarında askeri güç kullanımı sanayinin gelişmesi ile daha da yıkıcı bir hal aldı. İktisadi güç unsurların kullanımı daha genişledi, hacmi arttı. Siyasi evlilikler önemini kaybetmeye başladi. Rehin usulü değişmedi ama mahiyeti değişti, çünkü saltanat üyelerinin etkinliği kalmadı. Bunun yerini hedef ülkedeki güçlü muhalefet grupları aldı. Ülkesinde siyasi otoriteye karş1 gelmiş, anlaşamamış, farklı düşünen aydın, yazar, gazeteci veya siyasi muhalifler, bu dönemin rehineleri olarak birer diplomasi aracı haline geldiler. 19. yüzyıl ve günümüz olayları hatırlanırsa, gerçekten yeni rehin usulünün pek çok örneklerini görmek mümkündür.

Sanayi inkılabından sonra benimsenen yeni bir diplomasi aracı da sermaye ve teknoloji ihracıdır. Sanayileşme yolunda önemli mesafeler alan özellikle İngiltere ve Fransa gibi devletler, o zamana kadar hiç başvurulmayan bir usulü, sermaye ihracı usulünü kullanmağa başladılar. Bu suretle nüfuz alanlarını daha güçlü bir şekilde ellerinde tutacaklardı. Bunun sonucu olarak daha 19. yüzyılın ilk yarısında, çoğu Londra ve Paris merkezli olan bankaların Osmanlı ülkesinin muhtelif vilayetlerinde (Mısır, İzmir, İstanbul, Selanik) şubeleri açıldı. Böylece artık Batı sermayesinin müesseseleri de kurulmuş oluyordu (Kurmuş, 1982; Tekeli ve İlkin, 1981).

Batılı sömürgeci devletlerin, sömürgelerinde nüfuzlarını daha iyi yerleştirmek için yeni bir unsur olarak teknoloji ihracı/yatırımları da bir diplomasi aracı olarak kullanmağa başladıkları görülmektedir. Böylece hem sömürge alanlarında teknoloji ihracıyla nüfuzlarını tahkim etmiş ve hem de sanayi mamullerini bu bölgelerde satmak yoluyla büyük kazançlar elde etmiş oldular. Bununla aynı zamanda sömürgeleştirecekleri ülkelerin yerli milli sanayilerinin gelişmesini de engellemişlerdir. Osmanlı yerli sanayiinin Batı menşeli mamul mallar karşısında uğradığı akıbet malûmdur. Tabii olarak teknoloji ihrac1 yoluyla sanayilerine gerekli olan hammaddeyi ucuz ve garantili olarak temin ettikleri gibi, mamulleri için de önemli pazarları ellerinde tutmuş oluyorlardı. Böylece sanayi inkılabından sonra teknoloji ihracı, dünya siyasi tarihine yeni bir diplomasi aracı olarak girmiş oldu. Zira daha önceki binyıllarda, yüzyıllarda bir devletin başka bir devletin topraklarında yatırım yaptığı görülmemiştir. Sermaye ve teknoloji ihracının sadece iktisadi boyutu yoktur, Batılılar yatırım yaptıkları bölgelerde siyasi ve kültürel nüfuzlarını da yerleştiriyorlardı. Buna paralel olarak, izinli-izinsiz yüzlerce okul açmışlardır.

Emperyalizmin, menfaatlerini her zaman desteklenen azınlıklarla sürdürmek mümkün olmayabilirdi. Tahrik ve teşvik edilecek unsurlar, her zaman bulunmayabilir veya bu unsurun nüfusu 
ve coğrafi dağılımları özerk-bağımsız bir devlet oluşturmaya uygun olmayabilirdi. Bu durumda o ülkenin kendi halkından, kendi tebaasından, kendilerine en azından düşman olmayan, onlara sempati duyan bir grubun yetiştirilmesi gerekiyordu. İşte meşhur Misyoner Mekteplerinin kuruluş ve gelişmesinin altında yatan asıl gerçek budur. Bu mektepler vasıtasıyla kültürel koloniler meydana getirecekler, iktisadi ve siyasi menfaatlerini bu koloniler vasitasiyla devam ettireceklerdir. Veya ileride kuracakları devletin idareci zümresini yetiştireceklerdi. Onun içindir ki, özellikle 19. yüzyılın ikinci yarısından itibaren başta Osmanlı coğrafyası olmak üzere emperyalizmin etki alanına giren dünyanın her bölgesinde misyoner mektepleri açılmağa başlanmıştır. Latin Amerika, Küba, bütün Afrika, İran, Çin, Japonya ve Pasifik Adalarında söz konusu devletlerin binlerce misyoner mektepleri açılmıştır. Bu yarışta ABD geç almakla beraber en fazla yayılan ve misyoner mektepleri açan devlet ünvanını aldı. O halde misyoner mektepleri de yeni dönemin yeni bir diplomasi aracı olup, emperyalizmin kültürel tabanını oluşturan bir kurumdur (Öztürk, 2014: 305; Aksu, 2008; Çoban Döşkaya, 2018; Esenkal, 2007).

\section{Yeni Diplomasi Aracı: Tedhiş/Terörizm}

\subsection{Tedhiş Dönemi}

Tedhiş, Arapça bir kelime olup, dehşet verici, tehdit, baskı, korkutma, katletme, bu yolla yıldırma anlamlarına gelir, günümüzde kullanılan terör kelimesinin eş anlamlısıdır. 19. yüzyılın yeni diplomasi aracıdır. Sanayi İnkılabı ile Fransız İhtilal fikirleri ve amaçlarının pratik hayata yansıması ve sömürgeci devletlerin, sömürge alanlarına sahip olma siyasetleri, bu konuda devletlerin rekabeti, milli menfaatlerinin korunması amacıyla, çok uluslu imparatorluklarda ayrılık hareketleri teşvik edildi. Sırp, Yunan, Eflak-Boğdan, Girit, Arnavutluk, Makedonya, Bulgar ayaklanmalarının temelinde bu siyaset bulunmaktadır. Her ayaklanmada İngiltere, Fransa, Rusya, AvusturyaMacaristan, sonraları İtalya ve ABD, milli menfaatlerinin gereği olarak mutlaka müdahil olmuşlardır. Batılı devletler, Rusya'nın Balkanlara yayılarak nüfuz sahibi olmasını istememektedir. İngiltere ve Fransa da birinin himayesinde kurulacak yeni bir devlet istemediklerinden, başlangıçta ayaklanma olan bölgelerde 1slahat yapılmasını uygun gördüler ve bunu Osmanlı Devletine kabul ettirdiler.

Balkan isyanlarında Rusya'nın özel bir yeri vardır. Panslavizm ideolojisinin nihai amacı olarak Rusya'nın himaayesinde büyük bir Slav Birliği kurmak, Yunanistan ile de meşhur Grek Projesini gerçekleştirmek istiyordu. Buna göre merkezi İstanbul olan büyük Bizans kurulacaktı. Bu ideal, günümüzde dahi Yunanlıların bağlı kaldıkları Megali İdea ideolojisi olacaktır.

Balkan isyanlarının gerisinde emperyalist devletlerin olduğu zikredilmişti. Yakın planda, sahada bu isyanların mahfili, merkezi olan başka kurumlar da vardı. Bunların başında kiliseler geliyordu. Bütün isyanların planlanması, ideolojik eğitimi, haberleşme, silah-mühimmat depolanması kiliselerde planlanıyordu. Başlangıçta dini niteliği olduğu için kiliseler, kısmen devletin denetiminden uzaktı. Daha sonra isyanların merkezinin kilise olduğu açıkça görüldü. Nitekim Rum isyanlarının merkezi patrikhaneydi. İşin başında bizzat Patrik V. Gregorios vardı ve ihaneti kesinleşince 22 Nisan 1821'de paskalya günü idam edildi. Sırp isyanlarının merkezi Sırp Kilisesi, Bulgarların Bulgar Kilisesi, Yunanlıların Yunan Kilisesi, kısaca her isyanın arkasında milli kiliseleri vard1.

Kiliselerden başka isyanların en büyük destekçileri misyoner mektepleriydi (Töreli ve Çoban Döşkaya, 2018). Her ülkenin Balkanlara yayılmış yüzlerce okulları vardı. Bu okullarda da ideolojik eğitim veriliyor, Türk düşmanlığı aşılanıyor, milliyetçilik duyguları tahrik ve teşvik ediliyordu. Keza söz konusu devletlerin konsolosları da bizzat isyanları idare ediyorlar, ülkelerinin diplomatik ilişkilerinin yanında isyanları planlıyorlar, onlara her türlü diplomatik desteği veriyorlardı.

Mevcut durumu bu şekilde özetledikten sonra, ayaklanmaların seyrine bakıldığında, isyanların şu kademeler halinde geliştiği görülmektedir: 
Birinci kademede, esen kuvvetli milliyetçilik cereyanları ile her yerde her zaman bulunabilecek bir bahane ile ayaklanma başlatılır. İkinci kademede, Osmanlı kuvvetleri tarafından dönemin tabiriyle asiler tenkil edilir. Üçüncü kademede, gene dönemin tabiriyle düvel-i muazzama olarak adlandırılan büyük devletler araya girer, taraflar 1slahat yapılması hususunda ikna edilir. Üçüncü kademede yeniden başlatılan ayaklanma ile muhtariyet-özerklik verilir ve nihayet dördüncü kademe bağımsızlık görüşmeleri başlatılır ve söz konusu devletlere bağımsızlık verilir. (Örneğin bu usul ve plan, günümüz PKK terörünün ortaya çıkması, gelişmesi, desteklenmesi süreci ile aynıdır. Aynı şekilde bir kısım Kürtlere bağımsızlık vaatleriyle ayrılık fikirleri aşılanmış, sonra bilinen basit sebeplerle ayaklandırılmışlardır. Terör, Türk ordusu tarafından tenkil edilince, emperyalist devletlerin diplomatik müdahaleleri ile görüşmeler teklif edilmiş ve giderek özerklik kademesine gelinmiştir.)

Balkanlardaki ayaklanmaların aracı da dönemin diliyle tedhiş idi. İsyan bölgelerinde etnik temizlik maksadıyla bütün Türk köylerine saldırılar düzenlendi. Köyler yakılmaya, insanlar katledilmeye başlandı, yağma ve tecavüz hareketleri dayanılmaz hal aldı, bu suretle halk göçe zorlandı. Aslında bugüne kadar fazla dillendirilmeyen Balkanlarda Türklere karşı yapılan katliamlar, tarihimizin en dramatik sayfalarını oluşturur. Sırbistan'da Türk köylerine saldırılar düzendi, halk Belgrad kalesine çekilmek zorunda kaldı. Makedonya'daki tedhiş-eşkıyalık hareketleri, Türklere karşı umumi katliam, yağma ve sürgüne dönüştü. Bulgar mezaliminin acıları halâ hafizalardadır. Bölgedeki Türkler bu tedhiş/terör hareketleri ile göçe zorlandılar. Halk yıllardan beri yaşadıkları ata topraklarını terk etmek zorunda kaldı. Anadolu'ya göç edenlerin yolları eşkıyalar tarafından kesilerek, değerinin çok altında sattıkları mallarının paralarını gasp ettiler (Karal, 1988).

Ne yazık ki, bu dönemde katledilen Türklerin kesin sayıları hakkında kesin bilgiler yoktur. Her halükârda katledilen Türklerin yüzbinleri aştığı hakkında bilgiler vardır (Aslantaş, 2007; Toprak, 2019; Aydın, 2005).
"[Justin] McCarthy, 1821-1922 yılları arasında yaklaşık 5,5 milyon Müslümanın Avrupa'dan sürüldüğünü ve 5 milyondan fazlasının öldürüldüğü ya da hastalık veya açlık sonucu öldüğünü tahmin etmektedir... Michael Mann 1914 Carnegie Endowment raporunda, bu eylemlerin Avrupa'da daha önce görülmemiş muazzam ölçüde cani etnik temizlik olarak tanımladığını aktarmaktadır. 20. yüzyıla girerken Balkanların Osmanlı kontrolündeki bölgelerde 4,4 milyon Müslümanın yaşamakta olduğu tahmin edilmektedir. Mariya Todorova'ya göre, 19. yüzyılın son 30 yılında bir milyondan fazla Müslüman Balkanları terk etti." (www.turkaramamotoru.com, t.y)

Tabi bu nüfusun büyük kısmının katledildiğini tahmin etmek zor değildir. Rumların yaptıkları katliamlar daha erken başlamıştı.
“Tripoliçe katliamı, Mora isyanı sırasında bölgede Türklere karşı yapılan katliamların en büyüğüydü. Şehrin Yunanların eline geçmesinden birkaç gün sonra şehre gelen Britanyalı Thomas Gordon, 8000 kişinin öldürüldüğünü tahmin etti. Katliamdan sadece köle olarak alınan bazı kadınlar ve fidye için tutulan tanınmış Türkler kurtulabildi. Justin McCarthy ise katliamda ölenlerin sayısının 35,000 olduğunu belirtir. Teodor Kolokotronis, katliamdan şu şekilde bahsetti: Cuma gününden pazara kadar Yunan askerleri kadın, çocuk ve erkekleri katletti. Tripoliçe ve çevresinde toplam 32 bin kişi öldürüldü. En sonunda bir ulak geldi ve katliam durdu." (www.turkaramamotoru.com, t.y)

$\mathrm{Bu}$ ulağın, isyanın destekçileri olan devletlerin temsilcilerinden geldiği açıktır. (Balkanlar ve Anadolu'da Yunanlıların yaptıkları zulüm hakkında bkz. Başbakanlık Devlet Arşivleri, 1996; T.C. Genelkurmay Başkanlığı, 1996; Yalazan, 1994; Yetkin, 2013). 93 Harbi olarak bilinen 1877-1878 Osmanlı-Rus Harbinde de Türklere karşı büyük katliamlar yapılmıştır.

“93 Harbi sırasındaki kayıplar hakkında farklı tahminler bulunmaktadır. Richrad J. Crampton, 130.000-150.000 kişilik toplu göçünün yaşandığını ve bunun yaklaşık yarısının Berlin Kongresi ile cesaret alıp ara döneminde geri döndüğünü ifade etmektedir. 
Dennis Hupchik ve McCarthy ise 260.000 kişinin kaybolduğu ve 500.000 kişinin mülteci olduğuna işaret etmektedir. Kemal Karpat ise 300.000 kişinin öldürüldüğünü ve 1-1,5 milyon kişinin göçe zorladığını ileri sürmektedir. Nedim İpek de buna konuda Karpat ile aynı rakamları vermektedir. Bir başka ABD kaynağı, savaş sırasında 400.000 Türkün katledildiği ve bir milyon Türkün göç etmek zorunda kaldığını belirtmektedir." (www.turkaramamotoru.com, t.y)

Bütün göçlerin sebebi, yukarıda belirtildiği gibi, asilerin tedhiş/terör hareketleri idi. Balkan göçleri, yakın tarihimizde siyasi, iktisadi ve sosyal bakımdan büyük sonuçları olan göçlerdir. Her şeyden önce emperyalizmin Balkanlarda ateşlediği ve her bakımdan desteklediği isyanlar, Osmanlı Devleti'nin koca Rumeli topraklarını kaybetmesi ve paylaşılması için bir diplomasi aracı olarak kullanılmıştır. Milyonlarca Türk katledilmiş, sürgün edilmiş, başka bir ifade ile etnik temizlik yapılmıştır. İşte tedhişin/terörün diplomasi aracı olarak kullanılmasının siyasi, sosyal ve iktisadi sonuçları, büyük Balkan coğrafyasının kaybı ve milyonlarca Türkün sürgün edilmesi olmuştur (Balkan göçleri hakkında detaylı bilgi için bkz: Şimşir, 1968; Şimşir, 2017; Halaçoğlu, 1994; İpek, 1994).

\subsection{Yeni Dönem /Vekâlet-Vesayet Savaşlarının Aracı Terörizm}

Dünya 20. yüzyılda iki büyük savaş gördü. Her iki savaşta toplam 70-80 milyon insan öldü, şehirlerin alt yapıları çöktü, sosyal ve siyasi hayat alt üst oldu. Dünya haritası değişti, o zamana kadar olmayan devletler doğdu.

Dünyada ilk defa atom bombası kullanıldı, birkaç saat içinde yüzbinlerce insan katledildi. Bundan sonra emperyalist devletler arasında nükleer silahlanma yarışı başladı. Günümüzde yer küreyi yedi defa patlatacak, yok edecek güçte nükleer bomba depolanmış bulunmaktadır.

Eski dönemlerde bilinmeyen, kapitalizm, sosyalizm ve komünizm gibi ideolojiler dünya siyasetine yön verdi. Dünya, bu sistemler temelinde iki büyük bloğa ayrıldı. Bu bloklar, NATO ve Varşova Paktı etrafında askeri ve siyasi güç olarak teşkilatlandılar. Nihayet bu çatışmalar, 1950-1952 yı1ları arasında Kore Savaşı ve 1968-1974 yılları arasında ABD'nin Vietnam'a saldırması ile dünya barışını tehdit eden büyük savaşlara dönüştü.

Artık dünya siyasetinde yeni bir diplomasi aracı vardı ki, o da ideolojiydi. Her iki blok, ideolojilerini yayarak sömürü düzenlerini devam ettirmek için ideolojilerini ihraç etmeye başladılar. İkinci Dünya Savaşından sonra yaklaşı 50 yıl boyunca ideolojik çatışmalar, Türkiye dâhil üçüncü dünya ülkelerinin mücadele alanı oldu. Avrupa, Orta Doğu, Orta ve Güney Amerika ve Afrika ülkelerinde, ideolojik çatışmalar, iktisadi ve sosyal buhranlar, nihayet darbeler ve sonuçları yakın tarihin önemli bir boyutunu teşkil etmektedir. Sovyetler Birliği'nin 1991 yılında dağılmasıyla birlikte dünya tek kutuplu hale geldi. ABD, adeta dünyanın tek hâkimi oldu. Avrupa da menfaatleri gereği olarak daima ABD'nin yanında yer aldı. Sovyetler Birliği dağılmış olmakla beraber, kuzey-güney denge siyaseti devam ediyordu. Rusya için daha çok güneye, sıcak denizlere inmek, Batı için de Rusya'nın yayılmasını engellemek, bu dengenin temeli idi. Nitekim 1979 yılında Sovyetler Afganistan'1 işgal etmişlerdi. Buna karşı, ABD Pakistan üzerinden Taliban'1 kurarak Sovyetlere karşı savaş için her bakımdan desteklemiştir. İşte bu, vekâlet yoluyla yapılan savaşlara ilk örnek kabul edilebilir.

Her iki dünya savaşının çok büyük insan kaybının yanında ekonomik olarak da çok pahalı olduğu görüldü. Bu noktada emperyalist ülkeler, mümkün olduğu kadar kendi kaynaklarını ve askeri güçlerini kullanmadan, vekâlet-vesayet yoluyla hedeflerini gerçekleştirmek için yeni bir usule başvurdular. Esas hedef, karşı ülkenin iktisadi güç kaynaklarını kontrol altına almak, kendilerine mahkûm etmek, sanayi, teknoloji ve sermaye bakımından kendilerine bağlı kılmaktı. Bu noktada Batının Türkiye'ye bakışı, 19. yüzyılda bir İngiliz başbakanının Türkiye için söylediği ifadesiyle, "zayıf fakat sadık bir müttefik" olarak görmek ve bu halde tutmak, fazla güçlenmesine izin vermemek, kendi kendisini idare edecek sınırlı gücü ve sanayiinin olduğu bir ülke olarak görmekti. 
Özellikle Sovyetlerin dağılmasından sonra başta ABD olmak üzere, Batının siyasi, iktisadi ve sosyal menfaatlerini temin etmesi planlanan "küreselleşme" siyaseti dünya gündemine getirildi. Bu yeni kavramın içinde bütün dünya devlet ve kültürlerinin payı ve rızası olduğu düşünülmemelidir. Tam tersine küreselleşmenin temelinde hâkim güçlerin doğruları ve kültürleri ve emperyalist emelleri vardır. Belki de bu yüzdendir ki, küreselleşme tek taraflı bir program haline gelmiştir. Esasen bu düşüncenin tarihi felsefi temelleri çok daha gerilere gitmektedir. Batının üstün irk nazariyesine dayalı tarihi gerekçelerini, buna bağlı olarak hâkimiyet düşüncesini küreselleşmede görmek mümkündür. Bu hâkim düşüncenin tarihi pratiği de Roma İmparatorluğudur. Dünyanın gelmiş geçmiş en büyük imparatorluğunu kuran Roma imparatorluğu, Batının ulaşmak istediği nihai hedef, ebedi ideal haline gelmiştir.

Öte yandan uygarlık alanında yapılan ilerlemenin pratik uygulamalarında Batı vardır. Dünya biliminin temelinin Avrupa olduğu zannedilmemelidir, Batı, o zamana kadarki bilimsel bilgiyi pratiğe uyarlamıştır. $\mathrm{Bu}$ yönüyle Batı, bilimin hemen her alanında da bir üstünlük sağlamış bulunmaktadırlar. İşte Avrupa'nın bu tarihi zemini, bugünün temellerini oluşturmakta ve hâkim güç olarak ortaya çıkmaktadır. Bu haliyle küreselleşme bir medeniyetin temsilcisi haline gelmektedir. Eğer geniş bir bakış açısından bakıldığında, küreselleşmenin Avrupa ve ABD'nin temsil ettiği Batı medeniyetinin temsil ettiği hedefler ve değerler yekünü olduğu görülür. Bu değerlerin temeli, Hıristiyanlık, Grek-Roma antik kültürü ve emperyalizme dayanmaktadır. Hedefleri ise, en genel ifadeyle tek merkezli dünya hâkimiyetidir. Tek merkezli dünya hâkimiyetinin temeli, Batı merkezli olup Hıristiyanlık, kapitalizm, serbest piyasa ekonomisi, tek dil (İngilizce) ve Avrupa kültürüdür. Fakat Batının dışında da farklı dünyalar, kültürler ve doğrular vardır. Bu durumda istenen hedeflere ulaşmak ve tek merkezli dünya hâkimiyetini kurmak pek de kolay değildir. O halde bu hâkimiyeti gerçekleştirmek için bazı diplomasi veya baskı unsurlarının kullanılması gerekmektedir. Bunlar şunlardır:
a) Askeri Unsur
b) İktisadi Güç
c) Kültürel Yayılma
d) Değişik Bahanelerle Yönetim Tarzlarına müdahale.

Küreselleşmenin bu araçları (diplomasi/baskı araçları) bir bütün olarak düşünülmelidir. Zira hepsi birbirlerini tamamlayan unsurlardır. Dünyanın askeri, iktisadi güç kaynaklarının çok büyük bir kısmını ellerinde tutan küreselleşmenin temsil ettiği Batı bloğu, dünya hâkimiyetini gerçekleştirmek için sözü edilen güç unsurlarını her firsatta kullanmaktadır. Son yarım yüzyılda meydana gelen olaylar tahlil edildiğinde bu husus açık olarak görülecektir.

Geçmişte olduğu gibi, ABD başta olmak üzere bütün küresel güçler, 20. yüzyılın iki dünya savaşı ortamında ve Soğuk Savaş döneminde, Orta Doğu'daki menfaatlerini Türkiye'nin toprak bütünlüğünde görüyorlardı. Çünkü Soğuk Savaş döneminde Sovyet tehdidi varken, Türkiye'nin toprak bütünlüğüne yönelik Büyük Kürdistan ve Büyük Ermenistan'ın kurulmasını öngören eski planların gündeme getirilmesi, Batının siyasi menfaatleri bakımından o anda uygun değildi. Ama Sovyet tehdidi ortadan kalktıktan sonra artık Türkiye'nin toprak bütünlüğüne ihtiyaç da yoktu. Hatta tam tersi, Türkiye'nin bölünmesi, Batı için daha da uygun olacaktı. Bu amaçla Wilson prensiplerinde yer alan Kürt devleti ile Büyük Ermenistan'ın kurulması gündeme getirildi. Bundan sonra iki yüz yıldan beri süregelen Türkiye'yi paylaşma projelerinin uygulama safhasına geçilebilirdi.

\section{Terörizm ve Türkiye}

Asya, Avrupa ve Afrika'nın birleştiği Anadolu tarihte başat rolü oynamıştır. Bu üç kıtanın geçiş yaptığı yere baktığımızda, dünyanın en eski ve en önemli suyolları, denizleri Türkiye'den geçmektedir. Anadolu'dan karayoluyla Basra Körfezi’ne, Hindistan'a ve Uzak Doğu’ya giden bir 
güzergâh vardır. Aynı şekilde Anadolu, Ege ve Marmara'dan Karadeniz'e açılarak Rusya'ya, Hazar'ın üzerinden Orta Asya'ya, hatta Hazar Denizi'nden Türkistan'a varılabilecek bir konumdadır. Güneyden bakıldığında Süveyş’i geçtikten sonra bütün Mısır ve Afrika'yı etkileyecek bir coğrafyadır. Büyük bir dünya haritasına bakıldığında Anadolu'nun üç kıtanın düğüm noktasında olduğu, bu haliyle dünyanın kalbi halinde bulunduğu açıkça görülecektir. Dolayısıyla Anadolu tarih boyunca coğrafi üstünlüğünü ve önemini hiçbir zaman kaybetmemiştir.

İşte Türkiye'nin bu stratejik konumu, Batı için büyük tehdit oluşturmaktadır. O halde Türkiye, ya kendilerine bağlı ve mahkûm bir ülke olmalı veya parçalanmalıdır. Esas plan hedefi budur, son yüzyıldan beri ülkemiz üzerinde yapılan planlar ve karşı karşıya olduğumuz meselelerin temelinde bu olgu vardır. Ve dikkat edilirse, günümüzde yaşanan olaylar, 19. yüzyıldan beri Türk devletinin parçalanması/paylaşılması, Boğazlar Meselesi, borçlar, sanayileşme gibi devam eden olaylardır. Dahası Birinci Dünya Savaşı'ndan sonra halledilemeyen meseleler, Sevr'in uygulanamaması, bu bağlamda Büyük Ermenistan ve Kürdistan'ın kurulamamasının günümüze yansımasıdır. Tarih zannedildiği gibi, geçmişte olup-biten bir olay değildir. Tam tersine sürekli, canlı ve halâ yaşadığımız bir olaydır. İşte bu noktada tarihin devamlılığına şahit olunmaktadır. Tarih anlayışımızdaki eksik/yanlış bakış açısı, tarihin bu sürekliliğini görmemizi engellemiştir.

Türkiye'ye karşı diplomasi aracı olarak kullanılan Kürt meselesine gelince, meselenin ortaya çıkışı ve tarihi sürecini tekrar ve malûmu ilam etmekten ziyade yakın dönem üzerinde durmak yerinde olacaktır.

Yukarıda bahsedilen kademelerin birincisinde, Avrupa'da kurdukları araştırma enstitülerinde, sözde bilimsel araştırmalarla bir asırdan fazla bir zamandan beri Kürtlerin ayrı bir millet olduğu, dil, etnografya bakımındın farklı oldukları hususunda yayınlar yapıldı. Daha çok efsanelere dayalı bir tarih uyduruldu. Kürtlerin atalarının Hurri, Hatti ve Med oldukları ileri sürüldü fakat bütün tezler çürütüldü. Ama her halükârda ayrı bir kavim oldukları, hem ideolojik Kürtlere hem de dünya kamuoyuna kabul ettirildi.

ABD öncülüğündeki emperyalizmin Türkiye ve bölge hakkındaki stratejisi, Sevr'de öngörülen Kürdistan ve Ermenistan'ın kurulmasına dayanmaktadır. Bu suretle Türkiye, İran, Irak ve Suriye'de dağınık halde yaşayan Kürtlerin kuracağı bir devlet, bu üç devleti bölecektir. Görünüşteki basit plan budur. Fakat dünyadaki dengeler, bölge ülkelerinin nüfus ve nüfuzları göz önüne alındığında bunun mümkün olamayacağı açıktır. Ama her şeye rağmen planlarını uygulamaya koymaktan vazgeçmediler.

ABD'nin stratejisinin başka bir boyutu da İsrail'in güvenliğidir. Doğu Akdeniz'in ve Süveyş Kanalı'nın kontrolü için İsrail, Batının Orta Doğu'daki en önemli stratejik müttefikidir. Unutmamak lazımdır ki, ABD ve ortakları, İsrail'in güvenliği için Irak'ı parçaladılar, kuzeyde İsrail için bir tehdit olan Suriye'yi de iç savaşla dağıttılar. Hatırlanacağı gibi, Suriye 1973 savaşında İsrail ordularını yenmiş, Taberiye Gölü'ne kadar ilerlemiş iken, ABD'nin Akdeniz'deki 6. Filosunun ateş desteği ile Suriye ordusu durdurulabilmişti. Öyleyse Suriye bu haliyle bir tehditti ve böyle kalmamal1, parçalanmalıydı. Onun için ABD'nin Orta Doğu stratejisinde Türkiye de aynı şekilde hedeftir, öyleyse parçalanması lazımdır.

Soğuk Savaş döneminde Sovyet tehdidi olduğu için bu planlarını bir müddet ertelediler. Çünkü müttefikleri Türkiye'nin bu yolla zayıflatılması siyasi olarak menfaatlerine uygun değildi. 1960'lardan itibaren her ihtimale karşı Türkiye hakkındaki planlarını yavaş yavaş gündeme getirdiler. 1974 Kıbrıs Barış Harekâtından sonra önce Ermeni ASALA Terör örgütü, diplomatlarımıza suikastlar düzenlemeye başladı. 1970'lerin sonlarında özellikle üniversite gençliği arasında Devrimci Doğu Kültür Ocakları gibi Marksist dernekler kuruldu. İstihbarat örgütleri tarafından PKK da bu dönemde kuruldu. Nihayet PKK, ilk eylemini 1984'te yaptı (Töreli, 2015). Bundan sonra PKK saldırıları hız kazandı. Doğu ve Güney Doğu Anadolu'da büyük bir tedhiş/terör havası hâkim oldu. Yüzlerce köy yakıldı, kadın, çoluk-çocuk genç ihtiyaç ayırımı yapmadan binlerce 
vatandaşımız katledildi. Vahşet derecesinde devam eden PKK terörü, binlerce köyün boşalmasına, eğitim, sağlık, bayındırlık gibi hizmetlerin aksamasına sebep oldu (Aşkın, 2020).

Suriye'de üstlenen terör örgütü, Körfez savaşından sonra ABD'nin kurduğu sisteme göre oluşturulan 36. paralelin kuzeyi güvenli bölge ilan edildi ve Türkiye'nin baskısı ile Suriye'den çıkarılan PKK, bizzat ABD tarafından Kuzey Irak'a taşındı. ABD ve ortakları PKK'ya her türlü idari, diplomatik kolaylığı sağladılar. Silah, mühimmat, muhabere araç-gereçleri ve diğer teknik donanım alanlarında hiçbir fedakârlıktan kaçınmadılar. Almanya, İngiltere, Fransa, Avusturya, İsviçre, İsveç, Norveç, Belçika, Hollanda, İtalya ve Yunanistan ile Güney Kıbrıs Rum Kesimi, Suriye, İran ve Rusya, PKK'ya her türlü desteği verdiler. PKK, iktisadi, sosyal ve kültürel alanlardaki teşkilatlanmalarını ve faaliyetlerini, sözde demokratik Avrupa ülkelerinde rahatça yürütmektedir.

Geçmişte saltanat üyelerinin karşı devlet tarafindan rehin edilmesi usulü günümüzde de devam etmektedir. Ama şimdi hedef ülkenin muhalefet unsurları, o ülke aleyhinde tahrik ve teşvik ederek kullanmaları, günümüz emperyalist devletlerin yeni diplomasi aracıdır. Türkiye hakkında hesabı olan bütün devletler, bir şekilde PKK'ya destek vermektedirler. Kırk yılı aşan bir zamandan beri ülkemize karşı adı konmamış bir savaş açılmıştır. Yapılan hesaplara göre, bugüne kadar terörle mücadelede 700 milyar dolar harcanmıştır. Bu sadece nakden harcanan meblağdır. PKK'nın yarattı̆̆1 terör ortamı ile en az aynı miktarda ekonomik kayıp vardır. Bu da yaklaşık 1,5 trilyon dolar yapmaktadır. Basit hesaplamalarla bile bunun ne kadar büyük bir meblağ olduğu ortadadır. Milli hasılamızdan bu servetin kaybı, ülkemizin ekonomisine büyük zarar vermiştir.

ABD ve ortaklarının hedefi, Türkiye'nin bölünmesidir, bu açıktır. Ancak yurt içinde terörle mücadelede başarılı olunca, öteden beri Kuzey Suriye'de yı̆̆ınak yapan ABD, burada PYD'yi kurup desteklemeye başladı. IşīD-PKK-PYD terör örgütlerinin tamamı ABD ve ortakları tarafindan kurulup desteklenmektedir. Böylece bugüne kadar hiçbir ülkeye karşı yapılmayan terörist saldırılar, Türkiye'ye karşı yapılmaktadır.

Öte yandan ABD ve ortakları, Kuzey Irak'ta bilinen siyaseti neticesinde özerk bir hükümet kurdular. Kuzey Irak'ta özerk bir hükümet kurmalarına rağmen, bağımsız bir devlet olarak tanıyamamaktadırlar. Hâlbuki BM'de ayaküstü alabilecekleri bir karar ile Kuzey Irak'ın bağımsızlığını tanıyabilirler. Ama bunun tahmin edilemeyecek sonuçları olduğu da bilinmektedir. Çünkü bölge ülkelerinin dışında Çin ve Rusya gibi küresel güçler vardır. Bağımsız devlet olarak tanınan Kuzey Irak'ın siyaseten yaşaması güçtür. Aynı zamanda Türkiye ve İran'ın girişimleri, iktisadi işbirlikleri ile bir zaman sonra, bu ülkelerden birisine iltihak edebilir. O zaman özellikle Türkiye daha büyütülmüş olacaktır, bu tehlikeyi göze alamayan ABD, şimdilik sadece bölgede özerk bir hükümete razı olmaktadır.

Kuzey Irak’ta böyle bir devletin yaşayamayacağının farkında olan ABD ve ortakları, Kuzey Suriye'den Akdeniz'e bir koridor açmak amacıyla, Suriye'de gene kendilerinin çıkarttığ 1 iç savaşın doğurduğu istikrarsız ortamda, öteden beri destekledikleri Kuzey Suriye'deki Kürtleri ayaklandırdılar. PKK/PYD, bölgede tedhiş/terör hareketlerine başladı. Bölgedeki Arap ve Türkmenleri göçe zorladı. Afrin'den başlayarak, Bab, Arap Pınarı, Rakka ve Kamışlı'ya hâkim oldular. Gene ABD’nin kurduğu IŞṠD de PKK/PYD ile işbirliği içinde bölgeye hâkim oldular.

Nihayet Türk ordusunun yaptığı Fırat Kalkanı, Zeytin Dalı ve Barış Pınarı harekâtları ile bu plan şimdilik akamete uğradı. Kuzey Suriye koridoru çöktü.

Bunda hedef açıktır, o da Türkiye'nin bölünmesidir. Böylece Batının kontrolünde bölgede kurulacak bir devlet, Türkiye, İran, Irak ve Suriye'yi de bölecek ve baskı altına alacaktır. Bu başarılınca arkasından Ermeni terörü yeniden canlandırılacak, Pontus meselesi gündeme getirilecektir. Özellikle Türkiye'nin parçalanması, bütün bölge için bir yıkım olacaktır. Böylece emperyalizmin önündeki en büyük engel kalkmış olacak ve bölgenin paylaşımı ve sömürülmesi kolaylaşmış olacaktır. 


\section{Sonuç}

Sanayi İnkılabından sonra sömürgeciliğin büyük boyutlara ulaşması, uluslararası rekabeti doğurmuş ve nihayet bu rekabet Birinci Dünya Savaşı ile sonuçlanmıştır. 20. yüzyıl boyunca bitmeyen rekabet ve paylaşım iddiaları ikinci bir savaşa sebep olmuştur.

Emperyalist ülkeler, milli menfaatlerinin gerçekleşmesi için yeni diplomasi araçlarını keşfettiler. Bu yeni araçların başında, 19. yüzyıldan beri Balkan isyanlarında kullanılan tedhiş/terör aracı idi. Terör ile Osmanlı Devleti'nin Rumeli toprakları paylaşıldı. Her ne kadar terörle bir yere varılamaz deniyorsa da tarih bunun tersine şahittir.

Emperyalizmin hedefi olan Türkiye'ye karşı terörizm, kırk yıldan beri diplomasi aracı olarak kullanılmaktadır. Hem ülke içinde hem de Irak ve Suriye'de terörizm, açıkça her türlü silah, araçgerek, idari ve diplomatik alanda açıkça desteklenmektedir.

Bütün bunlar göz önünde cereyan eden malûm olaylardır. O halde karşı tedbir olarak neler yapılmalıdır, bu konudaki tekliflerimiz ne olmalıdır? Bunları şu şekilde özetleyebiliriz:

Her şeyden önce zihinsel bir değişime ihtiyaç vardı. Bugüne kadar Batı karşısında daima edilgen bir tavır alınmıştır. Atılacak her adımda ABD ve Avrupa'nın politikaları önem taşıyordu. Her yıl 24 Nisanlarda ABD başkanlarının Ermeni Meselesi hakkında hangi terimi telaffuz edeceği büyük bir merak ve endişe konusu olmuştur. Bu zihniyetten kurtulup, kendi gücümüze güven esasında politikalar geliştirilmelidir.

Artık teknoloji sır değildir. Türkiye de her türlü teknolojiye sahip olabilecek kabiliyettedir. $\mathrm{Bu}$ konuda da Batının üstünlüğü, önemini kaybetmiştir. Zira nükleer enerji, Hindistan, İsrail ve İran'da dahi vardır. Türkiye de pekâlâ bu teknolojiyi üretebilecek güçtedir.

Uluslararası politikada mütekabiliyet/karşılıklılık esastır. O halde bize karşı düşmanlık besleyen, hangi gerekçe ile olursa olsun teröristlere kol kanat geren ülkelere karşı siyasi ve ekonomik karşı tedbirlere başvurulmalıdır. Pek çok anlaşmalarla bağlı olduğumuzdan dolayı kolay olmadığını bildiğimiz ABD’nin üsleri kapatılabilir veya sınırlandırma getirilebilir. Artık hiçbir önemi kalmayan AB'ye müracaatımızı da en kısa zamanda çekmeliyiz.

Diplomasi araçlarının en güçlüsü, hiçbir zaman önemini kaybetmeyen askeri güç kullanımıdır. Emperyalist devletler, sömürge düzenlerini ve dünya hâkimiyetlerini askeri güçleri ile kurdular. O halde Türkiye de askeri ve ekonomik bakımdan güçlü olmalıdır. Nitekim Türk ordusunun Irak ve Suriye'ye yaptığı askeri harekâtlar, bilinen planları bozmuştur. Artık şu bir gerçektir ki, Türkiye coğrafyasının hâkimidir. Coğrafi üstünlük, askeri güç ile birleştirilince, olumlu sonuçlar alınmaktadır.

Bundan başka diplomasi araçları da ihmal edilmemelidir. Emperyalistlerin tarihte yaptıkları katliamlar TBMM'de alınan kararlarla kınanmalı, dünya kamuoyuna ve uluslararası mahkemelere taşınmalıdır. Onlara ülke kaynaklarından herhangi bir surette faydalanmalarına asla izin verilmemelidir. Her hususta hükümetler resmi olarak açıkça beyanatlarda bulunamayabilirler. $\mathrm{Bu}$ durumda sivil toplum örgütleri aracıllğıyla milli politikalarımıza uygun faaliyetler yapılabilir. Meselâ, sivil toplum kuruluşlarımız 6 ve 9 Ağustos gününü Japonya'nın Acısını Paylaşma Günü ilan edebilir, bu tarihlerde yapılan törenlere katılabilirler. Hele bunun sosyal medyada yayıldığ 1 düşünülürse, ABD’nin tavrı merak konusu olacaktır. Unutmamak lazımdır ki, bizim Batıya muhtaç olduğumuzdan daha fazla Batı da bize muhtaçtır.

\section{Kaynakça}

Aksu, A. (2008). “Türkiye'de Yabancı Okullar Üzerine Yapılan Çalışmalar.” Türkiye Araştırmaları Literatür Dergisi, 6(2): 207-241 
Aslantaş, S. (2007). Osmanlı'da Sirp İsyanları: 19. Yüzyılın Şafağında Balkanlar. Kitap Yayınevi.

Aşkın, H. (2020). Terör ve Algl Yönetimi. Yayın B.

Aydın, M. (2005). Balkanlar'da Isyan/Osmanlı-Ingiliz Rekabeti Bosna-Hersek ve Bulgaristan'daki Ayaklanmalar 1875-2876), Yeditepe Yayınları.

Başbakanlık Devlet Arşivleri Genel Müdürlüğü, Osmanlı Arşivi Daire Başkanlığı. (1996). Arşiv Belgelerine Göre Balkanlarda ve Anadolu'da Yunan Mezalimi II.

Çoban Döşkaya, F. (2018). “Amerikan Board ve Misyoner Corinna Shattuck'un Urfa Faaliyetleri.” Akademik Tarih ve Düşünce Dergisi, 5(14): 84-119.

Esenkal, E. (2007). Yabancı Ülkeler Tarafindan Osmanlı Coğrafyasında Açılan Okullar. Yayımlanmamış Yüksek Lisans Tezi Trakya Üniversitesi Sosyal Bilimler Enstitüsü, Edirne.

Halaçoğlu, A. (1994). Balkan Harbi Strasında Rumeli'den Türk Göçleri (1912-1913). TTK

Yayınlar1, https://doi.org/10.9737/hist.2018.587.

İpek, N. (1994). Rumeli'den Anadolu'ya Türk Göçleri (1877-1890), TTK Yayınları.

Karal, E. Z. (1988). Osmanlı Tarihi VI-VII, TTK Yayınları.

Kurmuş, O. (1982). Emperyalizmin Türkiye’ye Girişi. Yordam Kitap.

Öztürk, M. (2014). Tarih Felsefesi. 3. Bask1, Akçă̆ Yayınları.

Şimşir, B. (1968). Rumeli'den Türk Göçleri. 3 c. Türk Kültürünü Araştırma Enstitüsü Yayını.

Şimşir, B. (2017). Balkan Savaşlarında Rumeli Türkleri/Kıyımlar-Kırımlar-Göçler 1821-1913. Bilgi Yayınları.

T.C. Genelkurmay Başkanlığı, (1996). Türk İstiklal Harbi, II nci Cilt, Batı Cephesi, 2 nci Kısım, Genelkurmay ATASE Yayınları.

Tekeli, İ., İlkin, S. (1981). Para ve Kredi Sisteminin Oluşumunda Bir Aşama: Türkiye Cumhuriyet Merkez Bankası. T.C. Merkez Bankas1 Yayınevi. https://doi.org/10.16992/asos. 12563

Toprak, S. (2019). 19. Yüzyllda Balkanlarda Ulusçuluk Hareketleri ve Avrupalı Devletlerin Balkan Politikası. Gece Akademi Yayınevi.

Töreli, T. (2015). PKK Terör Örgütü. Türkiye Âlim Kitaplar1.

Töreli, T., Çoban Döşkaya, F. (2018). "Amerikan Board Misyoneri Olive L. Parmelee Andrus ve Mardin.” D. Karacoşkun, O. Köse (Ed), Geçmişten Günümüze Tarihten İzler içinde (201249 ss.), Berikan Yayınevi.

Türk Arama Motoru. "Müslüman-Türk Katliamları." Erişim adresi https://www.turkaramamotoru.com/musluman-turk-katliamlari-40299.html

Yalazan, T. (1994). Türkiye'de Yunan Vahşet ve Soy Kırım Girişimi. Genelkurmay Yayını.

Yetkin, Ç. (Ed). (2013). Yunan'ın Anadolu'daki Zulmü: Vahşet (Kızllhaç Raporu). (Çev. Necdet Ekinci), 2. Baskı, Gürer Yayınları. 